\title{
Comparison of estimators for monitoring long-term population trends in deer mice, Peromyscus maniculatus, on the California Channel Islands
}

\author{
Catherin A. Schwemm ${ }^{1, *}$, Charles A. Drost ${ }^{2}$, John L. Orrock ${ }^{3}$, \\ Timothy J. Coonan ${ }^{4} \dagger$, and Thomas R. Stanley 5 \\ ${ }^{1}$ Institute for Wildlife Studies, Box 1104, Arcata, CA 95518 \\ ${ }^{2}$ U.S. Geological Survey, Southwest Biological Science Center, Flagstaff, AZ 86001 \\ ${ }^{3}$ Department of Integrative Biology, University of Wisconsin, Madison, WI 53706 \\ ${ }^{4}$ National Park Service, Channel Islands National Park, Ventura, CA \\ ${ }^{5}$ U.S. Geological Survey, Fort Collins Science Center, Fort Collins, CO 80526
}

\begin{abstract}
Capture-recapture methods are commonly used to estimate abundance and density of wild animal populations. Although a variety of sophisticated analytical techniques are available to evaluate capture-recapture data, vertebrate monitoring programs often lack the resources (e.g., time, personnel, and/or analytical expertise) to apply these methods. As an alternative, simple population indices, such as counts of unique individuals, may provide sufficient information to detect meaningful changes in population size. In this study we investigated whether a population index, easily generated from mark-recapture data under all conditions, might be used to provide valid ecological information for managers interested in long-term population trends of deer mice (Peromyscus maniculatus) on the California Channel Islands. In practice, determining the efficacy of estimating abundance from mark-recapture data and indices using empirical data (as opposed to simulated data) is difficult given the scarcity of long-term data sets that describe real populations. Using mark-recapture data that span 18 years $(n=122$ trapping events, $>12,000$ marked individuals) for deer mice on 2 of the islands, we compared density estimates obtained from several commonly used mark-recapture models and also compared these estimates to index counts. Populations of island deer mice are extremely dynamic; estimated densities over the data period varied from 0 to $>1200 \mathrm{mice} / \mathrm{ha}$. Density estimates from models in program CAPTURE and program DENSITY, as well as from model-averaged Huggins models, were strongly correlated with each other and with the density index. Densities calculated by the models and the index showed similar patterns of population variation and trend over time for all 5 sites. For long-term population monitoring and assessment of population trends in deer mice, our findings suggest that the use of a simple index may provide adequate understanding of ecologically relevant population changes, though data collection methods that allow for more detailed analyses using advanced modeling techniques should be maintained.
\end{abstract}

RESUMEN.—Los métodos de captura y recaptura se utilizan comúnmente para estimar la abundancia y la densidad de las poblaciones de animales silvestres. Aunque, existe una gran variedad técnicas analíticas sofisticadas para evaluar los datos de captura y recaptura, los programas de monitoreo de vertebrados a menudo carecen de recursos (e.g. tiempo, personal y/o experiencia analítica) para aplicar estos métodos. Como alternativa, los índices de población simples, tales como el conteo de individuos, pueden proporcionar información suficiente para detectar cambios significativos en el tamaño de la población. En este estudio investigamos si un índice de población, fácilmente generado a partir de datos de marca y recaptura bajo todas las condiciones, podría usarse para proporcionar información ecológica válida a los gestores interesados en las tendencias poblacionales a largo plazo de los ratones ciervos (Peromyscus maniculatus) en las Islas del Canal de California. En la práctica, es difícil determinar la eficacia de las estimaciones de abundancia por medio de datos e índices de marca-recaptura utilizando datos empíricos (a diferencia de los datos simulados), debido a la escasez de bases de datos a largo plazo que describan poblaciones reales. Utilizando datos de marca-recaptura de ratones ciervos durante 18 años $(n=122$ casos de captura, $>12,000$ individuos marcados) en dos de las islas, comparamos las estimaciones de densidad obtenidas mediante varios modelos comúnmente utilizados de marca-recaptura y también comparamos estas estimaciones con el índice de conteo. Las poblaciones de ratones ciervos son extremadamente dinámicas; y las densidades estimadas durante este período variaron de 0 a más de 1200 ratones/ha. Las estimaciones de densidad de los modelos del programa CAPTURA, del programa DENSIDAD y de los modelos promediados de Huggins se correlacionaron fuertemente entre sí y con el índice de densidad. Las densidades calculadas por los modelos

*Corresponding author: schwemm@iws.org
†Retired 
y por el índice mostraron patrones similares de variación poblacional y de tendencia a lo largo del tiempo en los cinco sitios. En cuanto al monitoreo poblacional a largo plazo y a la evaluación de las tendencias poblacionales en ratones ciervos, nuestros resultados sugieren que el uso de un índice simple puede proporcionar información adecuada de los cambios ecológicamente relevantes en la población, aunque los métodos de recolección de datos que permitan análisis más detallados a través de técnicas avanzadas de modelado, deberían mantenerse.

A key consideration in the development of long-term monitoring programs for animal populations is how abundance will be measured and compared over time (Pollock et al. 2002, Field et al. 2005). Because the true number of animals present is rarely known, studies of wild populations commonly use methods that estimate population size (White et al. 1982). For long-term monitoring the optimal estimation approach should be consistent over time, robust over the range of variation in the target population, and appropriate for use with the available data. Moreover, the approach used to estimate population size should be one that managers can readily implement given widespread constraints of personnel, time, and expertise encountered in most wildlife monitoring programs (Strayer et al. 1986, Caughlan and Oakley 2001, Witmer 2005, Marsh and Trenham 2008, Perkins et al. 2013).

Data collected to estimate animal populations often take the form of capture-recapture data, in which animals are caught, uniquely marked, released, and potentially recaptured. Two general approaches to estimating population abundance and density from capturerecapture data are available. First, indices of abundance are the simplest measures to calculate and are based on the number of unique individuals detected during the sampling period (Slade and Blair 2000, McKelvey and Pearson 2001, Hopkins and Kennedy 2004). Such indices are usually derived from the number of animals caught and marked, but indices can also utilize results from other forms of detection (e.g., camera traps where individuals can be identified by sight; Skalski et al. 2005) and may be further scaled by unit effort (e.g., days of trapping). Although indices are straightforward to apply across a wide range of conditions, they are inherently negatively biased relative to actual population sizes (Nichols and Pollock 1983, Slade and Blair 2000, MacKenzie et al. 2003). Moreover, a valid comparison of indices over time for the same population requires a consistent relationship between the index and the true population size (e.g., there is no change in capture probability over the periods of interest). Therefore, care must be taken when comparing index-based estimates among populations or sampling periods (Slade and Blair 2000, McKelvey and Pearson 2001; but see Watkins et al. 2010).

In addition to indices, a number of statistical methods have been developed that use capture-recapture data to estimate population size (Conn et al. 2006). Methods that statistically analyze capture-recapture data generally provide more realistic estimates of abundance than do indices and are often more appropriate for single surveys (e.g., Cormack 1968, Otis et al. 1978, Nichols and Pollock 1983, Grimm et al. 2014; but see McKelvey and Pearson 2001). Many factors that vary between trapping sessions (e.g., weather, actual population size, habitat condition) contribute to the degree of bias and the precision of estimates for a given data set, such that the consistent application of a single "one-size-fits-all" model structure over time is not always justified (Boulanger and Krebs 1994, Slade and Blair 2000). Furthermore, when sample sizes are small, data are often insufficient to estimate capture probabilities and model results become less reliable (Menkens and Anderson 1988, Skalski and Robson 1992, Hammond and Anthony 2006). For example, previous studies have noted that the nested subgrid estimation procedure in CAPTURE is data intensive, requiring large grids, high capture probabilities, and as many as 10 or more trapping occasions (Wilson and Anderson 1985, Rosenberg et al. 1995). Because these methods require a unique data structure and considerable expertise in terms of model building and fitting, effectively applying these methods is often problematic (Marsh and Trenham 2008).

To estimate density, the abundance estimate (calculated from either an index or a model) is applied to the area over which the sampled population is thought to exist. The extent can be the area included in the trapping grid or it can be a larger area that includes habitat outside of the grid considered to be within the home range of the captured animals (effective trapping area [ETA]; 
Gerber and Parmenter 2015). Although there are several methods of estimating ETA (see Methods section), the key consideration for investigators is whether to use grid area only or whether and how to calculate and apply an ETA (Efford 2004, Ivan et al. 2013, Gerber and Parmenter 2015). The question is particularly important for long-term monitoring programs during which analysis methods should be consistent and valid under all conditions over time (Hopkins and Kennedy 2004).

In this paper we utilize a robust markrecapture data set to compare and contrast multiple analysis methods that estimate abundance and density of deer mice (Peromyscus maniculatus) in order to evaluate how well indices compare to results from other methods. Channel Islands National Park (CINP) has been monitoring deer mouse populations on the islands for several decades, so we used data from 5 trapping grids on the 2 islands with the longest trapping histories (Santa Barbara and San Miguel Islands). The data set covers not only a very long period of consistent sampling but also the extreme temporal and spatial variabilities in mouse population abundance (at one site ranging from 0 to 350 captures per 300 trap nights within a period of a few years). We evaluated rates of model failure (those events where models provided a highly unrealistic estimate or no estimate) and the level of agreement between results from models and indices for each trapping event. We also compared several methods of estimating ETA and examined apparent population trends from all approaches. Finally, we discuss whether it is appropriate to use indices as an alternative to statistical models for detecting population trends within the scope of the CINP deer mouse monitoring program given the realities of time and funding shortfalls that often preclude advanced analyses.

\section{METHODS}

\section{Study Area}

San Miguel Island (SMI) is the westernmost of the 4 northern Channel Islands, located approximately $70 \mathrm{~km}$ southwest of the city of Santa Barbara, California. San Miguel Island is of moderate size $\left(37 \mathrm{~km}^{2}\right.$ [14 mi²]) compared to the other islands and experiences the harshest weather conditions because of its location. This island supports a large population of the native island fox (Urocyon littoralis), an important predator of deer mice. Very different conditions exist at Santa Barbara Island (SBI), a small $\left(2.6 \mathrm{~km}^{2}\left[1 \mathrm{mi}^{2}\right]\right)$ and relatively isolated island $65 \mathrm{~km}(40 \mathrm{mi})$ south-southeast of the northern Channel Islands. Because of SBI's very small size, island foxes and other mammalian predators are not found there, conditions which allow deer mice to reach extremely high densities (Drost and Fellers 1991).

We report data from 2 trapping grids on SBI and 3 grids on SMI (Fig. la, b). Annual grassland and maritime coastal scrub are the 2 predominant habitats on these islands, so the 5 grids were established at representative sites in each habitat large enough to accommodate a trapping grid. On SBI, one grid is located in a largely homogenous stand of nonnative annual grasses and one grid is in maritime coastal scrub dominated by giant coreopsis (Leptosyne gigantea), a large shrub common across all of the islands. We included data from 25 and 30 sampling events ( 3 nights each) from the 2 SBI grids, respectively, between 1992 and 2008. On SMI, one grid is also located in a relatively homogenous grassland and the other 2 grids are in different phases of maritime coastal scrub-one dominated by coastal goldenbush (Isocoma menziesii) and giant coreopsis and the other by bush lupine (Lupinus albifrons). We included data from 21 , 24 , and 22 sampling events, respectively, from the grids on SMI between 1993 and 2008.

\section{Field Sampling}

Trapping methods are described in the deer mouse monitoring protocol developed for CINP (Fellers et al. 1988; see also Drost and Fellers 1991, Schwemm and Coonan 2001). Mark-recapture sampling using live traps was conducted in the spring (before the annual breeding season) and fall (after most or all reproduction is complete). Sherman live traps (H.B. Sherman Traps, Inc., Tallahassee, FL) were placed $7 \mathrm{~m}(\sim 23 \mathrm{ft}$.) apart at each of 100 points in $10 \times 10$ grids (total grid size $3969 \mathrm{~m}^{2}$ or $\sim 0.4$ ha $[\sim 1$ acre]). The 7 -m trap spacing reflects typical deer mouse movements at higher densities on the islands (Fellers et al. 1988). Traps were baited with rolled oats, checked each morning, and closed during the day; each trapping session typically lasted 3 nights. Mice were marked with individually numbered ear tags (\#1005-1, National Band \& 


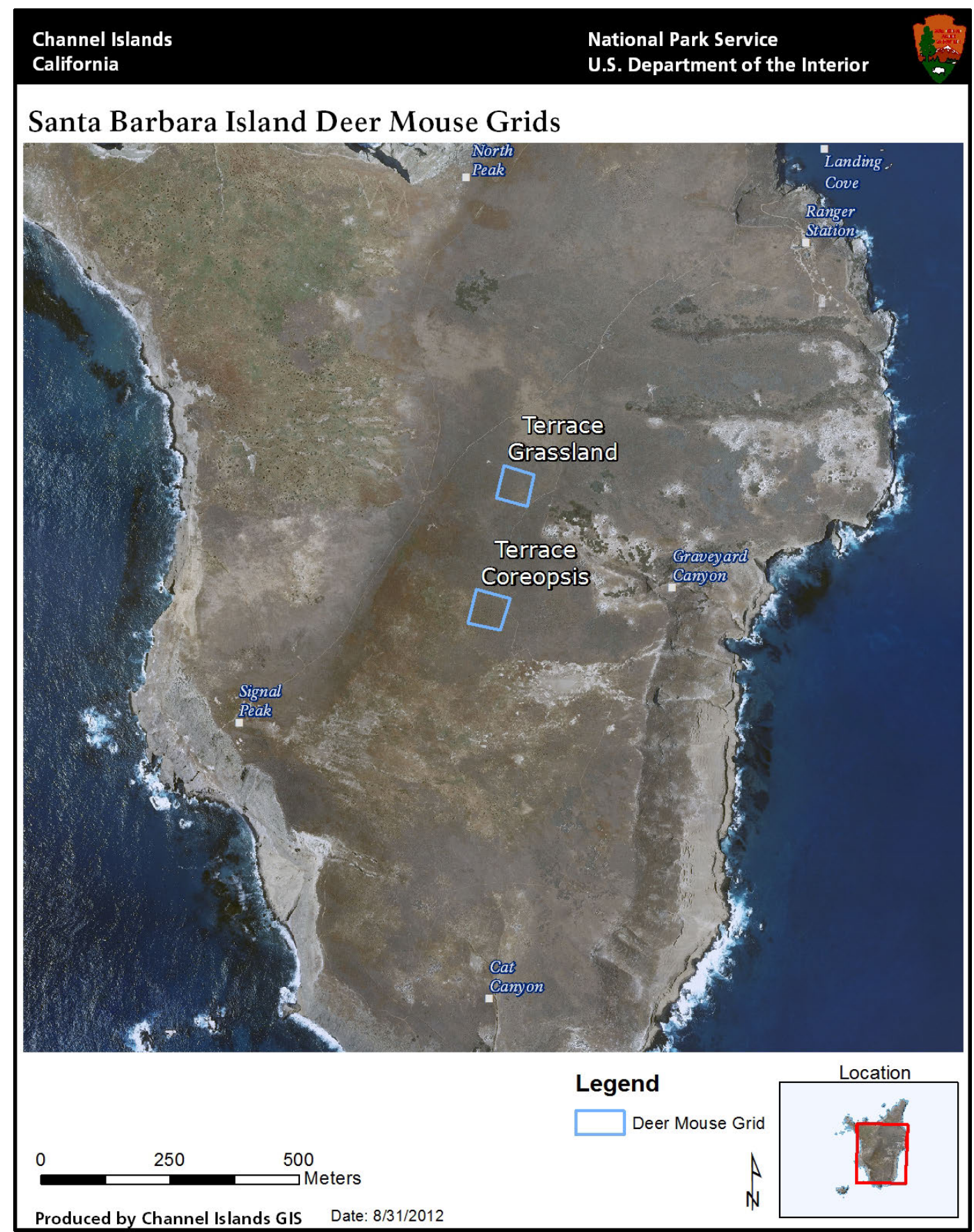

Fig. la. Deer mouse (Peromyscus maniculatus) trapping grids: Santa Barbara Island, Channel Islands National Park, California. Figure courtesy of the National Park Service.

Tag Co., Newport, KY) and data were recorded on sex, age (adult, subadult, or juvenile, based on pelage), and weight. Because of the short time span of the trapping sessions and the long period between the spring and fall sampling, each 3-night event was assumed to be independent and the population assumed to be closed (Stanley and Richards 2005). Sampling 


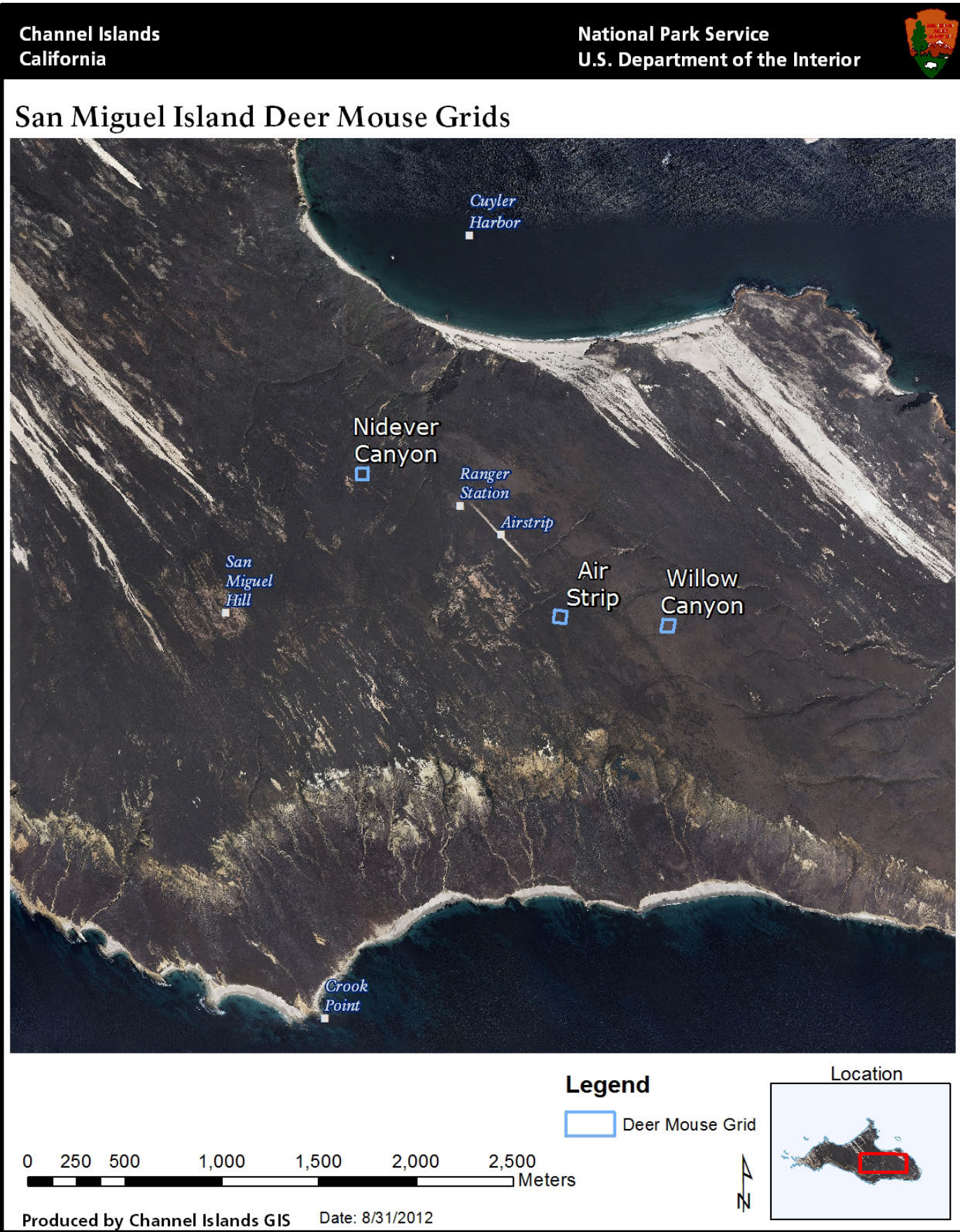

Fig. 1b. Deer mouse (Peromyscus maniculatus) trapping grids: San Miguel Island, Channel Islands National Park, California. Figure courtesy of the National Park Service.

was conducted in accordance with the American Society of Mammalogists' guidelines for the capture, handling, and care of mammals (Sikes and Gannon 2011).
Data Analysis

We first calculated a simple density index by dividing the number of unique individuals 
captured over the sampling period $\left(\mathrm{M}_{\mathrm{t}+1}\right.$; notation used by Otis et al. 1978) by grid area without a buffer strip (cf. Slade and Blair 2000, McKelvey and Pearson 2001). We then compared the density index for each trapping event with density estimates from 5 modeling approaches: CAPTURE-R ("Recommended," described below) and CAPTURE $\mathrm{M}_{\mathrm{h}}$ from program CAPTURE, DENSITY-MLE and DENSITY-IP from program DENSITY (Efford et al. 2004), and the Huggins models (Huggins 1991). CAPTURE software conducts a series of analyses that test for population closure (meaning assumptions are made that no individuals enter or leave the sampled area during the trapping period and there are no births or deaths), estimate capture probabilities, and then evaluate goodness of fit of 8 candidate models to the data. These models include a null model $\left(\mathrm{M}_{\mathrm{o}}\right)$ that assumes equal capture probabilities for all individuals and models that assume individual heterogeneity in capture probability $\left(\mathrm{M}_{\mathrm{h}}\right)$, behavioral response to trapping $\left(\mathrm{M}_{\mathrm{b}}\right)$, time variation over the course of the trapping $\left(\mathrm{M}_{\mathrm{t}}\right)$, and combinations of these factors (Otis et al. 1978, White et al. 1982).

A classifier based on discriminant analysis uses goodness of fit and other statistics in CAPTURE to predict the model that best fits the data and then selects this as the "recommended" model for estimation. The CINP protocol directs that the recommended model should be applied in most cases unless there are obvious reasons not to do so (Fellers et al. 1988). The various models in CAPTURE can provide very different estimates, however, so without a fair level of expertise it is difficult for most field personnel to know how to make such a determination. Because other studies have indicated that incorporating individual heterogeneity in capture probabilities is a realistic reflection of natural animal populations and that model $\mathrm{M}_{\mathrm{h}}$ generally performs well (Manning et al. 1995, Boulanger and Krebs 1996, Davis et al. 2003, Parmenter et al. 2003), for this analysis we compared only $M_{h}$ and the selected model (if it was not $\mathrm{M}_{\mathrm{h}}$ ).

A common method of estimating ETA is to add a virtual buffer strip around the grid, where the width of the buffer strip is estimated in some manner. In CAPTURE, buffer width is estimated using a nested subgrid approach and a weighted nonlinear least squares procedure (Otis et al. 1978). Once the buffer is estimated, density estimates in CAPTURE are calculated by dividing the model-derived abundance estimate by ETA.

The DENSITY-MLE and DENSITY-IP modeling approaches have their foundations in the work of Efford (2004) and Efford et al. (2004). DENSITY models jointly estimate density and capture probability as a function of the distance between traps and the estimated home range centers of individual animals, so no additional steps are required to estimate ETA. The DENSITY-MLE approach is based on a maximum likelihood model that is used for estimation, whereas the DENSITYIP approach uses an inverse prediction method for estimation. We calculated the DENSITYMLE and DENSITY-IP density estimates using the default settings in program DENSITY (i.e., a Poisson spatial point process, a halfnormal detection function, and a single-live detector type).

The Huggins modeling approach is based on the models described in Huggins (1991), with point and error estimates obtained using program MARK (White and Burnham 1999). We considered multiple candidate models for the Huggins approach. The most general model analyzed was additive and allowed capture probabilities $(p)$ and recapture probabilities (c) to vary across capture occasions (time) and among individuals as a function of sex and weight. We analyzed all possible subsets of this model where $p$ and $c$ were not constrained to be equal, and then we constrained $p=c$ and analyzed all possible subsets of an additive time, sex, and weight model. We ranked models by their $\mathrm{AIC}_{c}$ values and computed the weights for the $i$ th model $\left(w_{i}\right)$ (Burnham and Anderson 2002). We deleted from consideration any models in which the numerical optimization routine failed to converge on reasonable values (e.g., one or more parameters were singular), as well as models with $w_{i}$ $<0.01$ (indicating that there was little support for the model). We used model averaging with the remaining models to obtain an estimate of abundance and its unconditional standard error (Burnham and Anderson 2002).

For the Huggins modeling approach, ETA was estimated following Parmenter et al. (2003) where ETA equaled the grid area plus a buffer strip width equal to half of the estimated mean maximum distance moved (MMDM) by mice on the grid. Here "maximum distance moved" 
TABle 1. Performance of different density estimators using mark-recapture data for deer mice (Peromyscus maniculatus) on the California Channel Islands. "No estimate" means the model failed to produce a numerical estimate. Extreme values were counted as estimates over 2 times greater than, or less than half of, all other estimates. "\% Total missed" = $\%$ No estimate $+\%$ Extreme values. The total number of trapping sessions with numerical estimates was 119.

\begin{tabular}{lccccc}
\hline Estimator & No estimate & Extreme values & \% No estimate & \% Extreme values & \% Total missed \\
\hline CAPTURE $\mathrm{M}_{\mathrm{h}}$ & 7 & 2 & 5.9 & 1.7 & 7.6 \\
CAPTURE-R & 7 & 5 & 5.9 & 4.2 & 10.1 \\
DENSITY-MLE & 13 & 4 & 10.9 & 3.4 & 14.3 \\
DENSITY-IP & 19 & 0 & 16.0 & 0.0 & 16.0 \\
Huggins & 0 & 2 & 0 & 1.8 & 1.8 \\
\hline
\end{tabular}

was the distance between the 2 farthest capture locations for each individual mouse, and MMDM was the mean of all of these values for the trapping period. As above, density estimates under the Huggins approach were calculated by dividing the model-averaged estimate by ETA.

Because we recognized that different methods of estimating ETA would likely affect density estimates, we used a simple correlation analysis to compare area estimates from the nested subgrid calculations of CAPTURE with the MMDM buffer strip calculation that we used in the Huggins estimates. We also compared the ETA estimates with corresponding abundance estimates from the Huggins models, with the expectation that average home range size and hence ETA should be smaller when there are more animals present (Wolff 1985, Ribble and Stanley 1998). Finally, because the primary objective of the CINP monitoring program is to track population changes over time, we compared the patterns of changes in numbers by using the different population estimation methods. This was done with a simple graphical analysis and comparison of density estimates, as well as whether there was agreement in the direction of trend (increase or decrease).

\section{Results}

\section{Method Comparisons}

The ability to yield density estimates varied among the different modeling approaches, and models failed to provide an estimate in approximately $10 \%$ of events (Table 1 ). The DENSITY-IP approach failed to produce an estimate most frequently (16\% of events) while the Huggins approach had no failures; the 2 CAPTURE modeling approaches were intermediate. Most failures (39 of 46 total) occurred when there were low numbers of individuals captured $\left(M_{t+1} \leq 40\right)$. Six of the failures for the DENSITY-IP method, however, were for $M_{t+1}$ when estimates ranged from 138 to 255 individuals. Similarly, most of the extreme values ( 10 of 13 values counted as extreme) were also when $\mathrm{M}_{\mathrm{t}+1}$ was low $(<50)$, but 3 extreme values were for values of $\mathrm{M}_{t+1}$ ranging from 101 to 171 . The CAPTURE-R model and DENSITY-MLE had the highest number of extreme values. Some of the extreme estimates were clearly due to problems with the procedures for calculating the effective area sampled during a trapping session, resulting in an unrealistically large area applied to the density calculation.

The relationships among the various methods used to calculate density were approximately linear and ranged from 1:1 to 1:1.25 in most cases and across the range of estimated densities ( $<5 /$ ha to over $1200 /$ ha). Pairwise comparisons of all density estimates from the 5 model-based approaches and the density index for the combined data from the 2 islands showed strong correlations for all combinations (Fig. 2). The DENSITY-MLE, DENSITY-IP, and Huggins density estimates showed the closest correspondence, with correlation coefficients ranging from 0.96 (DENSITY-MLE and DENSITY-IP compared to Huggins) to 0.97 (between DENSITY-MLE and DENSITY-IP). The density index had a relatively strong correlation with density estimates from all modeling approaches $(r=0.89-0.94)$ except the DENSITY-IP estimates $(r=0.82)$. The model selected as CAPTURE- $\mathrm{R}$ varied across events depending on data but was most commonly the null model, $\mathrm{M}_{\mathrm{o}}$ (Fig. 3). The correlation coefficient between the CAPTURE-R model and CAPTURE $\mathrm{M}_{\mathrm{h}}$ estimates was 0.84. CAPTURE$\mathrm{R}$ had the weakest correlation to all other estimators, ranging from 0.82 to 0.85 .

There were evident trends in comparisons among the modeling approaches. Both the 


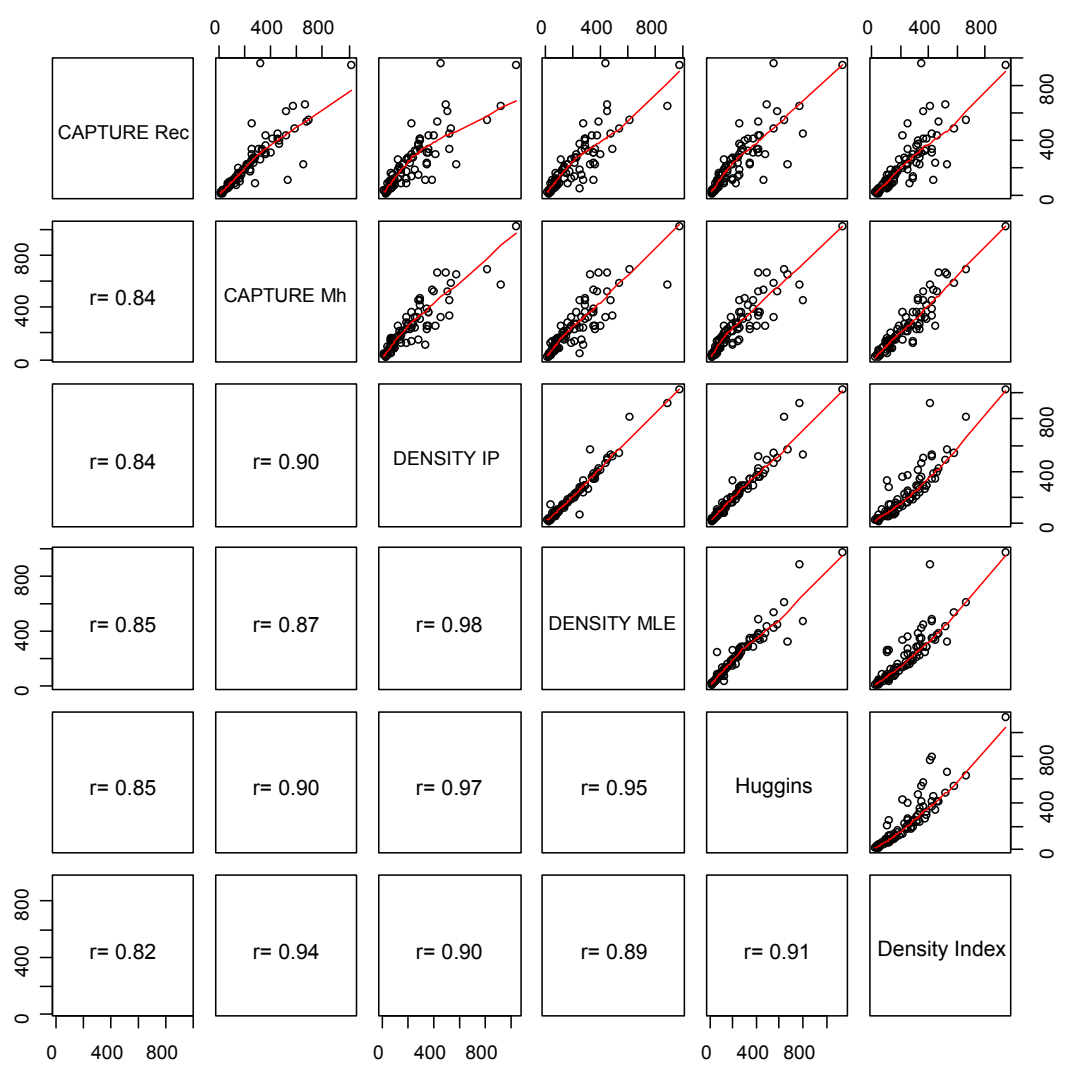

Fig. 2. Pairwise comparisons of density estimates for long-term population studies of deer mice (Peromyscus maniculatus) on the California Channel Islands. In this figure, "CAPTURE Rec" is CAPTURE recommended model, "CAPTURE $\mathrm{M}_{\mathrm{h}}$ " is CAPTURE model Mh, "DENSITY IP" is the inverse prediction approach, "DENSITY MLE" is the spatial MLE approach, "Huggins" is the Huggins approach, and "Density Index" is the total number of unique individuals captured divided by the sampling grid area. Numbers on the $x$ - and $y$-axes are deer mouse density (individuals per hectare). All $P<0.001$.

CAPTURE-R model and the density index tended to produce lower estimates than the other estimators. However, the relationship between the index and the Huggins approach was nearly 1:1. Except for the density index, the Huggins approach tended to produce higher estimates compared to the other estimators. The density estimates from the DENSITY-IP approach were conspicuously higher than the other approaches, except for DENSITY-MLE (approximately 1:1) and Huggins (lower).

\section{Effective Area Sampled and Density Estimation}

In our comparison of the ETA estimates using the nested subgrid method (implemented in CAPTURE) and the MMDM method (used with the Huggins models), some area estimates from both methods were clearly extreme and unreasonable based on our understanding of the behavior of deer mice on the islands (e.g., values $>2.6$ ha, over 6.5 times the size of the grid boundaries). Even after eliminating such extreme values, the ETA estimates using the 2 methods were not significantly correlated $(r=-0.18, P=$ 0.086 ), though there is some evidence of a relationship between the 2 approaches. In many instances and across a range of capture totals, the nested subgrid calculations failed to calculate any area sampled beyond the grid and showed no correlation with measures of population size ( $r=-0.01, P=0.922$; Fig. $4 \mathrm{a})$. Estimates of ETA calculated using MMDM also showed variation at low capture totals but overall were much more consistent and were inversely related to population numbers $(r=$ $-0.34, P<0.001$; Fig. $4 \mathrm{~b}$ ), ranging from approximately $7600 \mathrm{~m}^{2}$ (low abundance) to $5000 \mathrm{~m}^{2}$ (high abundance). Density estimates 


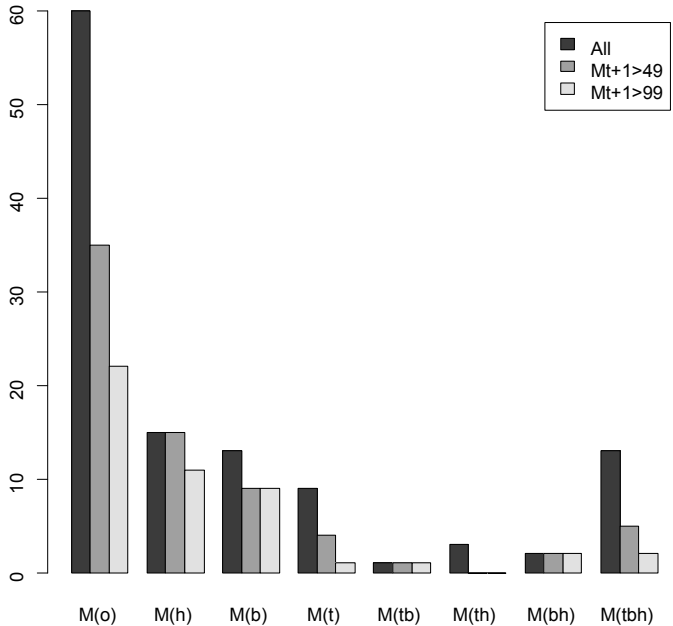

Fig. 3. Frequency of CAPTURE recommended models selected by program CAPTURE for long-term population data of deer mice (Peromyscus maniculatus) on the California Channel Islands. In addition to the null model $\left(\mathrm{M}_{\mathrm{o}}\right)$, the different models take into account individual heterogeneity in the population $\left(\mathrm{M}_{\mathrm{h}}\right)$, behavioral response to trapping $\left(\mathrm{M}_{\mathrm{b}}\right)$, time variation over the course of the trapping $\left(\mathrm{M}_{\mathrm{t}}\right)$, and combinations of these factors. The bars for each model show numbers for all trapping sessions, sessions with at least 50 individuals captured $\left(\mathrm{M}_{\mathrm{t}+1}\right)$, and sessions with at least 100 individuals captured.

from CAPTURE-R and Huggins tracked closely with each other when MMDM was used to estimate the ETA.

The wide variation and lack of agreement among the different approaches suggested that ETA was contributing significantly to the determination of density in those cases where ETA was used; in this study CAPTURE$\mathrm{R}$ and CAPTURE $\mathrm{M}_{\mathrm{h}}$ used the nested subgrid method and the Huggins models used MMDM. For this reason we compared the abundance estimates alone from CAPTURE $\mathrm{M}_{\mathrm{h}}$, CAPTURE-R, the Huggins models, and $\mathrm{M}_{\mathrm{t}+1}$ (Fig. 5). The correlations for the abundance estimates were substantially stronger than the correlations between the density estimates, with results from CAPTURE-R generally having the weakest relationships to other methods. Correlations among $\mathrm{M}_{\mathrm{t}+1}$ and the model-based abundance estimates ranged from 0.92 to 0.98 , while correlations between the density index and model-based density estimates, in contrast, ranged from 0.82 to $0.91(P<0.001$ in both cases $)$. Finally, patterns of change between point estimates tracked closely among all 3 approaches for

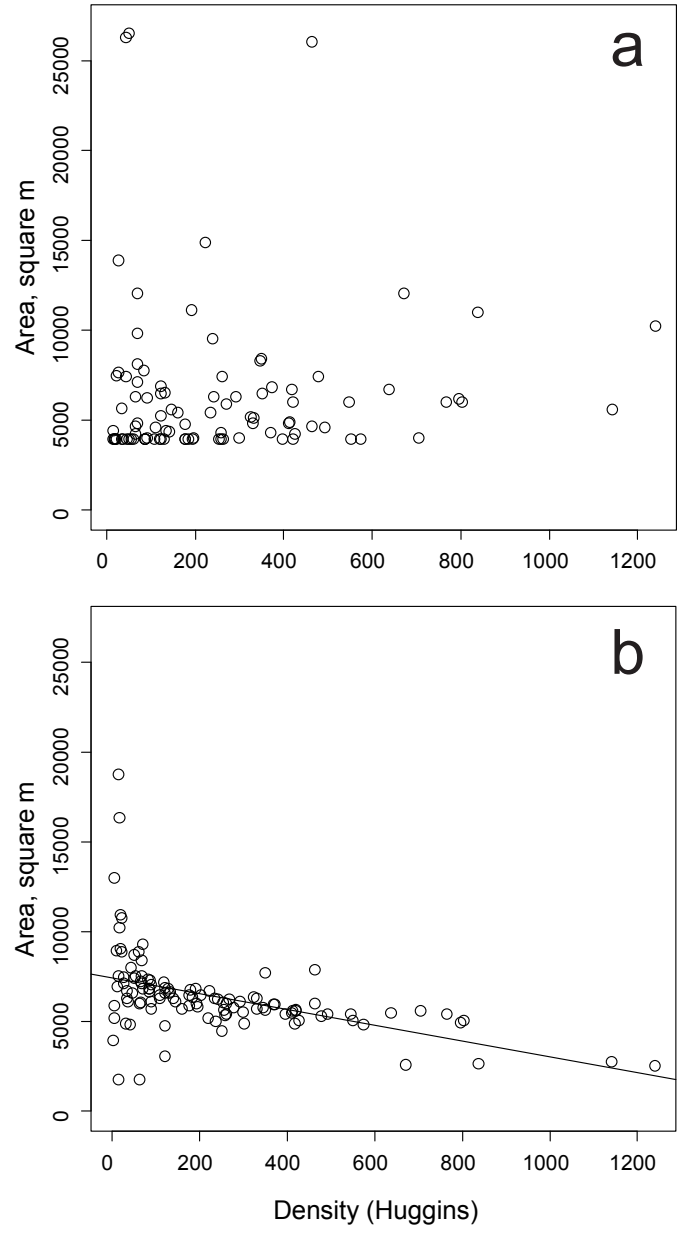

Fig. 4. Estimates of effective area sampled compared to density estimates calculated by the Huggins method for a long-term mark-recapture study of deer mice (Peromyscus maniculatus) on the California Channel Islands. Estimates of effective area sampled were calculated using (a) the nested subgrid method of program CAPTURE and (b) a buffer strip equal to the mean maximum distance moved (MMDM) by mice.

most sessions; Fig. 6 presents these results for SBI (SMI results were similar).

\section{Discussion}

There has long been discussion and debate over the usefulness, reliability, and validity of using indices to estimate population abundance and density (Nichols and Pollock 1983, Slade and Blair 2000, McKelvey and Pearson 2001, Hopkins and Kennedy 2004). The results of our analyses suggest that using a population index for examining changes in 


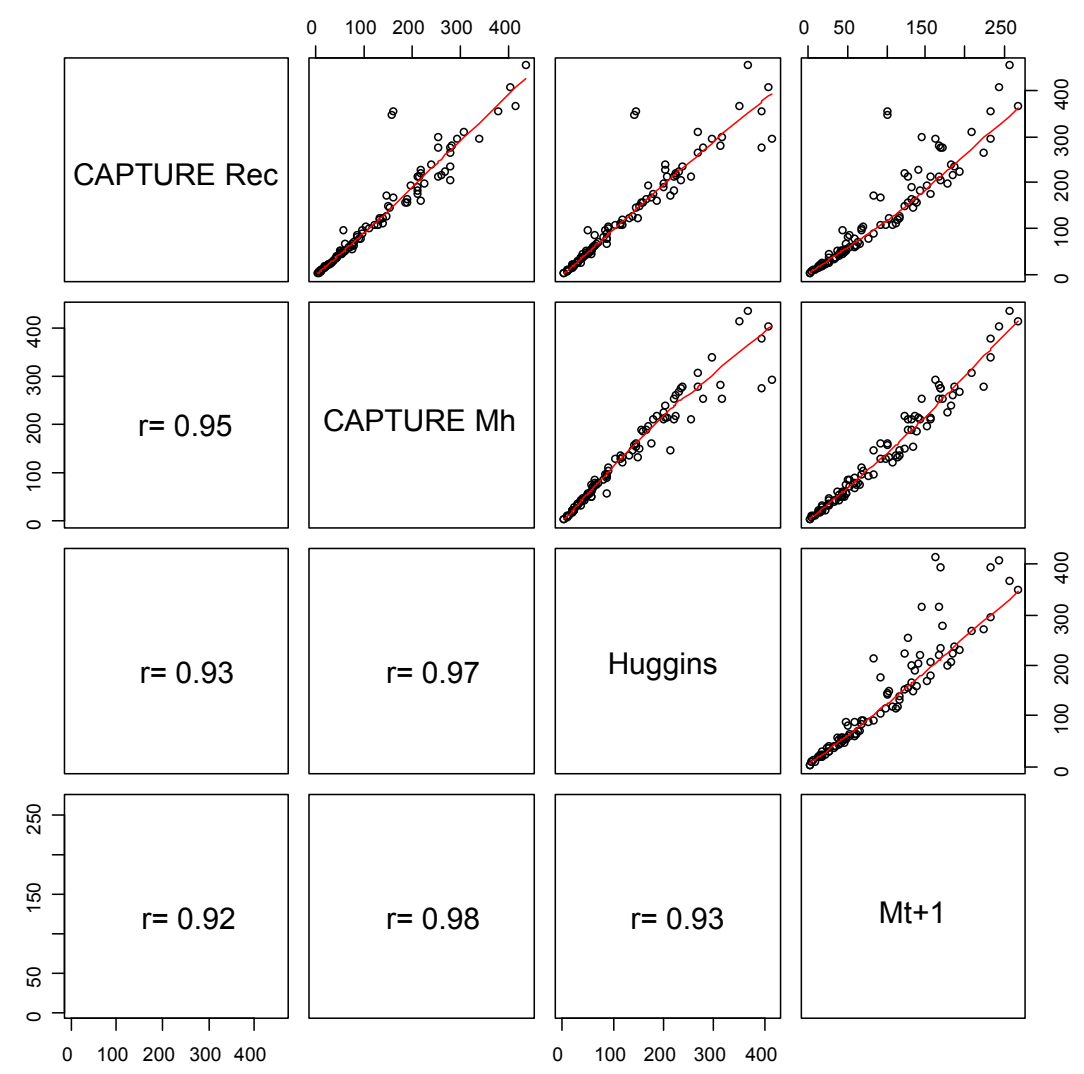

Fig. 5. Comparison of abundance estimates from program CAPTURE (recommended model and model $\mathrm{M}_{\mathrm{h}}$ ), Huggins models, and number of unique individuals captured $\left(\mathrm{M}_{\mathrm{t}+1}\right)$ for long-term monitoring data of deer mice (Peromyscus maniculatus) on 2 of the California Channel Islands. The values from the modeling approaches are population estimates, not density.

mouse populations on the Channel Islands provides valuable information that is strongly correlated with estimates from more complex analytical techniques. Although mark-recapture estimators are useful for evaluating particular hypotheses (Otis et al. 1978, Thompson et al. 1998), they may require substantial time and expertise to implement, and they may also fail to produce reasonable estimates or any estimate when data are sparse or recaptures are low (Table 1; Otis et al. 1978, Efford 2004). This failure occurred with relatively high frequency for our data, though the Huggins models had clear advantages over the other modeling approaches, providing estimates for all sessions with no evident extreme values. Our results also showed that indices do not adequately reflect the highest extremes in populations that fluctuate over a very wide range but do provide reasonable estimates at low population levels when model-based estimators frequently fail. At extremely high population levels, the index (and the models to a lesser extent) potentially suffered from trap saturation, a situation wherein so many animals are caught that most traps are eventually closed and additional animals go undetected (Otis et al. 1978).

Our results indicated that ETA values contributed to the differences observed in the density estimates among modeling approaches that used ETA. Our results showed highly variable ETA estimates calculated using nested subgrids as well as the absence of a relationship between ETA and population size (which is ecologically unrealistic). In contrast the ETA estimates calculated using MMDM were relatively consistent (Fig. 3) and showed a declining trend with higher numbers, reflecting more closely what we would expect if deer mouse home ranges do, in fact, contract in response to higher densities (Pimm and 


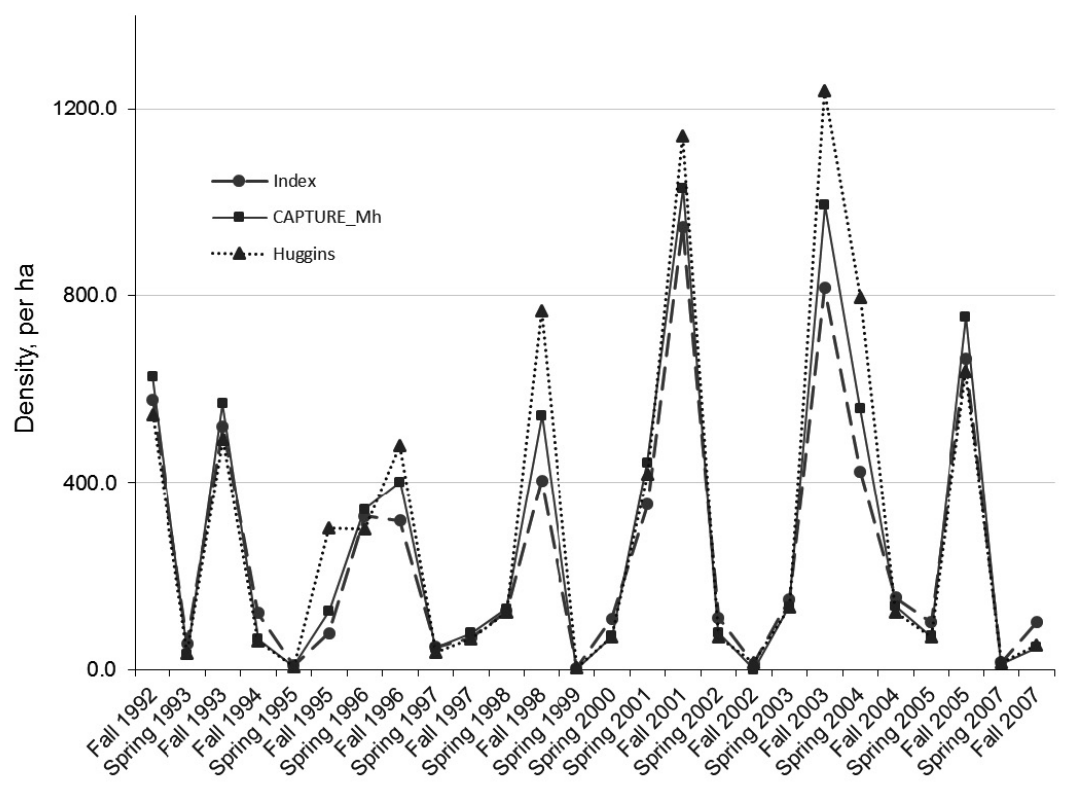

Fig. 6. Trends in deer mouse density on a monitoring grid on Santa Barbara Island, Channel Islands National Park, California, as indicated by 3 different modeling approaches: a simple index value, the CAPTURE $\mathrm{M}_{\mathrm{h}}$ approach, and the Huggins approach. No data were collected in 2006.

Rosenzweig 1981, Wolff 1985). The MMDM calculation of ETA is likely to be conservative and subject to variability with a small number of sampling occasions. However, without increasing the number of traps or the length of the trapping period, this measure appears to be the most stable and reliable estimator for calculating effective sampling area. Among the model-based estimators that we evaluated, the Huggins approach incorporating covariates produced estimates for all trapping sessions, with very few estimates that were extreme. The Huggins approach requires a comparatively intensive data collection effort and a level of sophistication and computational expertise to implement but has been shown to produce estimates with a high level of accuracy and precision (Parmenter et al. 2003).

We suggest that the relationship between very low diversity of small mammal species on the islands and relatively high capture rates contributed to the strong performance of the density index relative to the model-based approaches. The small mammal community on the California Channel Islands consists of only one species at our trapping sites. The near-absence of interspecific competition likely reduces the heterogeneity of capture probabilities for deer mice both within and across sessions. Prior work has indicated that index counts are least reliable for comparing populations across species but may be sufficiently reliable when making intraspecific comparisons (Slade and Blair 2000). Our data generally support this assertion because capture probabilities were consistently high, averaging 0.44 . Assuming independence, this means that on average the probability that an individual was captured at least once over the 3 capture occasions was 0.82 . Thus we would expect the index in our study to track true abundance rather well.

\section{Future Directions and Applications for Monitoring in Channel Islands National Park}

Long-term monitoring of animal populations is essential for understanding how environmental conditions affect populations and for predicting how population viability and persistence may change in the future. Channel Islands National Park was established in 1980 by legislation that explicitly directed managers to monitor key natural resources because they were important to ecosystem function, a concept now described as surveillance monitoring (Hutto and Belote 2013). Deer mice are an important component of depauperate island 
faunal communities and function as prey, seed, and egg predators and hosts for diseases of human concern (e.g., Sin Nombre virus; Orrock et al. 2011). Information on population trends of island deer mice resulting from monitoring has provided key insights into interspecific relationships between mice as prey of barn owls (Tyto alba; Drost and Fellers 1991) and island foxes (Urocyon littoralis; Coonan et al. 2010), as egg predators of Scripps's murrelets (Synthliboramphus scrippsi; Schwemm and Martin 2005, Schwemm et al. 2005), and as seed predators on native island plant species (Schwemm 2014). We suggest that for this type of monitoring, indices provide a simple and cost-effective approach for determining seasonal and annual changes in mouse abundance. Because the density index tracked very closely with all of the model-based approaches under most conditions, we have few reservations about substituting it for the current CAPTURE protocol or other modeling approaches and further suggest that valid density estimates comparable over time are obtainable with the current 3-night trapping protocol.

Although our results suggest that an index is sufficient for monitoring changes in mouse population dynamics on the Channel Islands, future studies that leverage the full power of mark-recapture approaches will be essential for addressing critical ecological hypotheses. Much remains to be learned from these data and future data regarding the important ecological role of Peromyscus on the islands and in other systems where they are common (Kauffman and Maron 2006, Dutra et al. 2011), as well as the role of long-term climatic variation affecting mouse survival and abundance. Applying advanced analysis methods to the CINP mouse data will be easily facilitated due to the original selection of field methods appropriate for multiple capture-recapture data analysis techniques, and we encourage CINP to continue supporting the existing deer mouse monitoring program.

\section{ACKNOWLEDGments}

The long-term fieldwork and data collection on which this study was based was developed, maintained, and supported by the National Park Service (NPS) and the program managers and staff at Channel Islands National Park. The list of these dedicated personnel is long, but we thank in particular G. Davis, B. Ehorn, K. Faulkner, and F. Ugolini. We thank the NPS Mediterranean Coast Network and S. Ostermann-Kelm for support in the deer mouse monitoring protocol review. Many people were involved in trapping, but particular thanks are due to $\mathrm{P}$. Martin and J. Savage. We thank C. Yackulic for a helpful discussion and review of the manuscript. For Thomas Stanley, funding was provided by the U.S. Geological Survey Fort Collins Science Center and the NPS Inventory and Monitoring Program. Catherin Schwemm thanks D. Garcelon for continued support and L. Bailey for early assistance with these concepts. John Orrock acknowledges support from the National Science Foundation (DEB 1439550). We thank R. Rudolph and the NPS for providing the maps of mouse trapping grid locations. Any use of trade, product, or firm names in this publication is for descriptive purposes only and does not imply endorsement by the U.S. government.

\section{Literature Cited}

Boulanger, J.G., and C.J. Krebs. 1994. Comparison of capture-recapture estimators of snowshoe hare populations. Canadian Journal of Zoology 72:1800-1807.

Boulanger, J.G., and C.J. Krebs. 1996. Robustness of capture-recapture estimators to sample biases in a cyclic snowshoe hare population. Journal of Applied Ecology 33:530-542.

Burnham, K.P., And D.R. Anderson. 2002. Model selection and multimodel inference: a practical information-theoretic approach. 2nd edition. Springer-Verlag, New York, NY.

Caughlan, L., and K.L. OaKley. 2001. Cost considerations for long-term ecological monitoring. Ecological Indicators 1:123-134.

Conn, P.B., A.D. Arthur, L.L. Bailey, and G.R. SingleTON. 2006. Estimating the abundance of mouse populations of known size: promises and pitfalls of new methods. Ecological Applications 16:829-837.

Coonan, T.J., C.A. Schwemm, AND D.K. Garcelon. 2010. Decline and recovery of the island fox: a case study for population recovery. Cambridge University Press, Cambridge, United Kingdom.

CoRmack, R.M. 1968. The statistics of capture-recapture methods. Oceanography and Marine Biology, Annual Review 6:455-506.

Davis, S.A., L.K. Akison, L.N. Farroway, G.R. Singleton, AND K.E. LESLIE. 2003. Abundance estimators and truth: accounting for individual heterogeneity in wild house mice. Journal of Wildlife Management 67:634-645.

Drost, C.A., AND G.M. Fellers. 1991. Density cycles in an island population of deer mice, Peromyscus maniculatus. Oikos 60:351-364.

Dutra, H.P., K. Barnett, J.R. Reinhardt, R.J. Marquis, AND J.L. ORRock. 2011. Invasive plant species alters 
consumer behavior by providing refuge from predation. Oecologia 166:649-657.

EFFord, M.G. 2004. Density estimation in live-trapping studies. Oikos 106:598-610.

Efford, M.G., D.K. Dawson, and C.S. Robbins. 2004. DENSITY: software for analyzing capture-recapture data from passive detector arrays. Animal Biodiversity and Conservation 27:217-228

Fellers, G.M., C.A. Drost, and B.W. Arnold. 1988. Terrestrial vertebrates monitoring handbook: Channel Islands National Park, California. National Park Service, Channel Islands National Park, Ventura, CA. http://www.mednscience.org/download_product/ $1041 / 0$

Field, S.A., A.J. Tyre, and H.P. Possingham. 2005. Optimizing allocation of monitoring effort under economic and observational constraints. Journal of Wildlife Management 69:473-482.

Gerber, B.D., and R.R. Parmenter. 2015. Spatial capture-recapture model performance with known small mammal densities. Ecological Applications 25:695-705.

Grimm, A., B. Gruber, and K. Henle. 2014. Reliability of different mark-recapture methods for population size estimation tested against reference population sizes constructed from field data. PLOS ONE 9(6):e98840

Hammond, E.L., AND R.G. Anthony. 2006. Mark-recapture estimates of population parameters for selected species of small mammals. Journal of Mammalogy 87:618-627.

Hopkins, H.L., AND M.L. KenNEDy. 2004. An assessment of indices of relative and absolute abundance for monitoring populations of small mammals. Wildlife Society Bulletin 32:1289-1296.

HugGins, R.M. 1991. Some practical aspects of a conditional likelihood approach to capture experiments. Biometrics 47:725-732

Hutto, R.L., and R.T. Belote. 2013. Distinguishing four types of monitoring based on the questions they address. Forest Ecology and Management 289: 183-189.

Ivan, J.S., G.C. White, and T.M. Shenk. 2013. Using simulation to compare methods for estimating density from capture-recapture data. Ecology 94: $817-826$.

Kauffman, M.J., and J.L. Maron. 2006. Consumers limit the abundance and dynamics of a perennial shrub with a seed bank. American Naturalist 168:454-470.

Manning, T., W.D. Edge, AND J.O. WolfF. 1995. Evaluating population-size estimators - an empirical approach. Journal of Mammalogy 76:1149-1158.

MacKenzie, D.I., J.D. Nichols, J.E. Hines, M.G. KnUtSON, AND A.B. FrankLin. 2003. Estimating site occupancy, colonization, and local extinction when a species is detected imperfectly. Ecology 84: 2200-2207.

Marsh, D.M., and P.C. Trenham. 2008. Current trends in plant and animal population monitoring. Conservation Biology 22:647-655.

McKelvey, K.S., and D.E. Pearson 2001. Population estimation with sparse data: the role of estimators versus indices revisited. Canadian Journal of Zoology 79:1754-1765.

Menkens, G.E., and S.H. Anderson. 1988. Estimation of small mammal population size. Ecology 69: $1952-1959$.
Nichols, J.D., AND K.H. Pollock. 1983. Estimation methods in contemporary small mammal capturerecapture studies. Journal of Mammalogy 64: 253-260.

Orrock, J.L., B.F. Allan, and C.A. Drost. 2011. Biogeographic and ecological regulation of disease: island area, precipitation, and predator richness are related to prevalence of Sin Nombre virus in island mice. American Naturalist 177:691-697

Otis, D.L., K.P. Burnham, G.C. White, and D.R. ANDERSON. 1978. Statistical inference from capture data on closed animal populations. Wildlife Monographs 62:7-135.

Parmenter, R.R., T.L. Yates, D.R. Anderson, K.P. Burnham, J.L. Dunnum, A.B. Franklin, M.T. Friggens, B.C. Lubow, M. Miller, G.S. Olson, et AL. 2003. Small-mammal density estimation: a field comparison of grid-based vs. web-based density estimators. Ecological Monographs 73:1-26.

Perkins, G.C., A.S. Kutt, E.P. Vanderduys, and J.J. PERRY. 2013. Evaluating the costs and sampling adequacy of a vertebrate monitoring program. Australian Zoologist 36:373-380.

Pimm, S.I., And M.L. Rozenzweig. 1981. Competitors and habitat use. Oikos 37:1-6.

Pollock, K.H., J.D. Nichols, T.R. Simons, G.L. Farnsworth, L.L. Bailey, and J.R. Sauer. 2002. Large scale wildlife monitoring studies: statistical methods for design and analysis. Environmetrics 13:105-119.

Ribble, D.O., and S. Stanley. 1998. Home ranges and social organization of syntopic Peromyscus boylii and P. truei. Journal of Mammalogy 79:932-941.

Rosenberg, D.K., W.S. Overton, and R.G. Anthony. 1995. Estimation of animal abundance when capture probabilities are low and heterogeneous. Journal of Wildlife Management 59:252-261.

Schwemm, C.A. 2014. Importance of early life stage limitations on recovering populations of Leptosyne gigantea, San Miguel Island, California. Monographs of the Western North American Naturalist 7:489-499.

Schwemm, C.A., J.T. Ackerman, P.L. Martin, and W. PERrY. 2005. Nest occupancy and hatching success of Xantus's Murrelets (Synthliboramphus hypoleucus) breeding on Santa Barbara Island, California during a twenty-year period. Pages 385-394 in Proceedings of the Sixth California Islands Symposium. National Park Service Technical Publication CHIS05-01, Institute for Wildlife Studies, Arcata, CA.

Schwemm, C.A., And T.J. CoOnan. 2001. Status and ecology of deer mice (Peromyscus maniculatus subsp.) on Anacapa, Santa Barbara and San Miguel Islands, California: summary of monitoring 1992-2000. National Park Service Technical Report 01-02, Channel Islands National Park, Ventura, CA.

Schwemm, C.A., AND P.L. Martin. 2005. Response of nest success of Xantus's Murrelets (Synthliboramphus hypoleucus) to native predator abundance, Santa Barbara Island, California. Pages 373-384 in Proceedings of the Sixth California Islands Symposium. National Park Service Technical Publication CHIS05-01, Institute for Wildlife Studies, Arcata, CA.

Sikes, R.S., And W.L. Gannon. 2011. Guidelines of the American Society of Mammalogists for the use of wild mammals in research. Journal of Mammalogy 92:235-253. 
SKalski, J.R., AND D.S. RobSOn. 1992. Techniques for wildlife investigations: design and analysis of capture data. Academic Press, San Diego, CA. 237 pp

Skalski, J.R., K.E. Ryding, and J.J. Millspaugh. 2005. Wildlife demography: analysis of sex, age, and count data. Elsevier Academic Press.

Slade, N.A., AND S.M. Blair. 2000. An empirical test of using counts of individuals captured as indices of population size. Journal of Mammalogy 81: $1035-1045$.

Stanley, T.R., AND J.D. RichaRds. 2005. Software review: a program for testing capture-recapture data for closure. Wildlife Society Bulletin 33:782-785.

Strayer, D., J.S. Glitzenstein, C.G. Jones, J. Kolasa, G.E. Likens, M.J. McDonnell, G.G. Parker, and S.T.A. PickETT. 1986. Long-term ecological studies: an illustrated account of their design, operation, and importance to ecology. Occasional Publication of the Institute of Ecosystem Studies, Number 2. 38 pp.

Thompson, W.L., G.C. White, and C. Gowan. 1998. Monitoring vertebrate populations. Academic Press, Cambridge, MA.

Watkins, A.F., J.L. MCWhirter, and C.M. King. 2010. Variable detectability in long-term population sur- veys of small mammals. European Journal of Wildlife Research 56:261-274.

White, G.C., D.R. Anderson, K.P. Burnham, and D.L. OTIS. 1982. Capture-recapture and removal methods for sampling closed populations. Rep. LA-8787NERP, Los Alamos National Lab, Los Alamos, NM.

White, G.C., AND K.P. BuRnham. 1999. Program MARK: survival estimation from populations of marked animals. Bird Study 46 (Supplement):S120-S139.

Wilson, K.R., AND D.R. ANDERson. 1985. Evaluation of a density estimator based on a trapping web and distance sampling theory. Ecology 66:1185-1194.

Witmer, G.W. 2005. Wildlife population monitoring: some practical considerations. Wildlife Research 32:259-263.

WoLfF, J.O. 1985. The effects of density, food, and interspecific interference on home range size in Peromyscus leucopus and Peromyscus maniculatus. Canadian Journal of Zoology 63:2657-2662.

Received 7 March 2017

Revised 2 October 2017

Accepted 12 January 2018

Published online 28 September 2018 